\title{
Clinical significance and characterization of AZT-resistant strains of HIV-1
}

\author{
mark A Wainberg, PhD, Ronald Rooke, BSc, Michel Tremblay, PhD, XuGuang Li, MD, \\ Michael A PARnIAK, PHD, QING GAO, MD, XIAO-JIAN YAO, MD, ChrIS TSOUKAS, MD, \\ JSG MONTANER, MD, M FANNING, MD, J RUEDY, MD
}

\begin{abstract}
MA WAINBERG, R ROOKE, M TREMBLAY, et al. Clinical significance and characterization of AZT-resistant strains of HIV-1. Can J Infect Dis 1991;2(1):5-11. A number of laboratories have now independently confirmed that zidovudine (AZT)-resistant strains of human immunodeficiency virus type 1 (HIV-1) may be isolated from patients undergoing prolonged therapy with this drug. In certain instances, such drug-resistant viral isolates have been obtained from patients with clinical acquired immune deficiency syndrome (AIDS), while in others, isolation of drug-resistant strains has been achieved in the case of HIV seropositive, asymptomatic subjects. Most of the evidence points to a series of mutations within the polymerase gene of HIV-1, which encodes viral reverse transcriptase, as being responsible for development of the drug-resistant phenotype. It further appears that over $50 \%$ of patients treated with AZT for periods longer than six monihs are likely to yield drug-resistant strains of HIV-1 in their circulation. Furthermore, the development of drug resistance soon after initiation of AZT therapy may potentially be correlated with the likelihood of AZT treatment failure. In several instances, cross resistance has been observed between AZT and other nucleosides being considered for potential therapy of HIV-1-associated disease.
\end{abstract}

Key Words: AZT, CD4+ cells, Lymphocytes, Resistance, Zidovudine

\section{Importance clinique et caractérisation des souches de VIH-1 résistantes à l'azidothymidine}

RESUME: Plusieurs laboratoires ont confirmé indépendamment que des souches du virus de l'immunodéficience humaine résistantes à l'azidothymidine peuvent être isolées chez les patients sous traitement prolongé. Dans certains cas, des isolats résistants ont été obtenus chez les patients atteints du syndrome d'immunodéficience acquise tandis que chez d'autres, les souches résistantes proviennent de sujets asymptomatiques infectés par le VIH. Selon la plupart des données, une série de mutations au sein de l'ARN polymérase du VIH-1, qui encode la transcriptase inverse virale, serait responsable de l'avènement du phénotype résistant au médicament. Il apparaît, de plus, que plus de la moitié des patients traités sous azidothymidine pendant plus de six mois présentent des souches de VIH-1 résistantes dans leur circulation. Plus encore, le développement de cette résistance au médicament peu après l'institution du traitement par AZT pourrait être en corrélation potentielle avec la probabilité d'échec thérapeutique. Dans plusieurs cas, une résistance croisée a été observée entre l'AZT et d'autres nucléosides qu'on envisageait d'utiliser dans le traitement des maladies associées au VIH-1.

St Paul's Hospital, University of British Columbia, Vancouver, British Columbia; Toronto General Hospital, University of Toronto, Toronto, Ontario; and Jewish General Hospital, Montreal General Hospital and McGill AIDS Centre, McGill University, Montreal, Quebec

Correspondence and reprints: Dr MA Wainberg, Jewish General Hospital, 3755, cote Ste-Catherine, Montréal, Québec H3T 1E2. Telephone (514) 340-8260. Fax (514) 340-7502 
$\mathrm{D}_{\mathrm{i}}^{\mathrm{n}}$ RUG RESISTANCE IS BECOMING AN INCREASINGLY important problem in medical virology. A number of studies have shown that drug-resistant strains of herpes simplex virus $(1,2)$, cytomegalovirus (3) and influenza virus (4) may be isolated with considerable frequency from patients receiving antiviral chemotherapy for protracted periods. There has been considerable discussion as to the likelihood that the long term clinical usefulness of each of acyclovir, ganciclovir and amantadine may eventually be compromised because of this problem.

More recently, it has been shown that drug resistance may develop in the case of human immunodeficiency virus type 1 (HIV-1)-infected individuals who are treated over long periods with 3'-azido-3'-deoxythymidine (AZT or zidovudine) (5-7). A number of groups have shown that AZTresistant strains of HIV-1 may be isolated both from patients with minimal HIV-1- associated disease, including asymptomatic subjects (6), and from patients with more advanced conditions, including the acquired immune deficiency syndrome (AIDS) $(5,7)$. The development of such drug resistance may be the consequence of mutations within the HIV-1 genome during the course of viral multiplication; drug pressure may permit the outgrowth of variants with decreased drug susceptibility. There is evidence that certain of the mutations which account for resistance to AZT may be located within the pol gene of HIV-1, which encodes viral RNA-dependent DNA polymerase (reverse transcriptase).

A number of studies have shown that treatment with AZT can prolong survival and improve quality of life for people suffering from HIV-1 infection, including AIDS $(8,9)$. Most recently, it has been demonstrated that treatment with AZT may diminish the likelihood of progression from an HIV-1 seropositive, asymptomatic state to more advanced disease (10). AZT acts by interfering with the formation of proviral DNA from viral parental RNA. This involves the blocking of viral reverse transcriptase activity, resulting in chain termination of proviral DNA, after viral penetration into the cytoplasm of the infected cell has occurred (Figure 1). It has recently been reported that AZT may be able to act as well after integration of proviral DNA into host cells has taken place

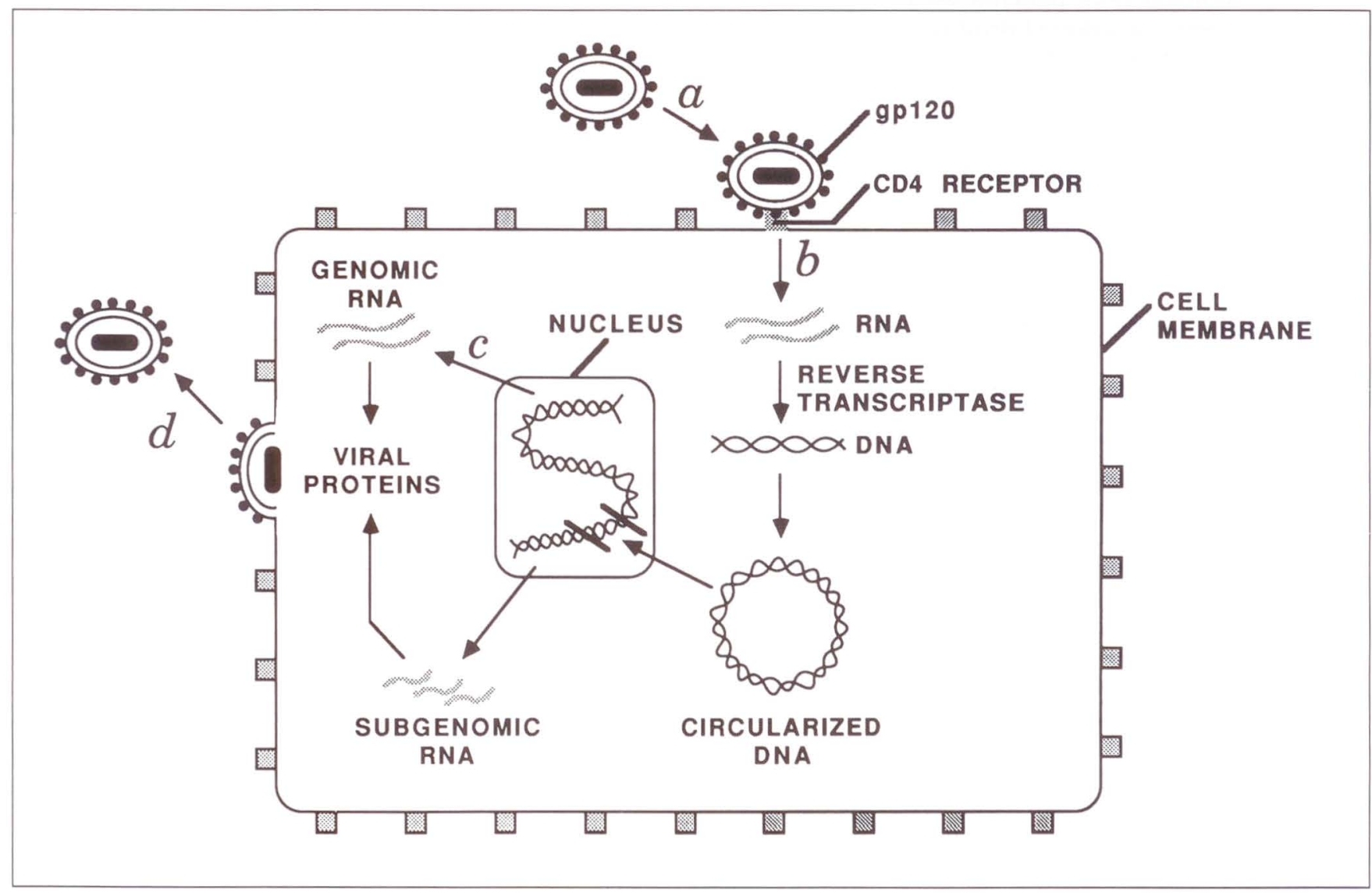

Figure 1) Intracellular replication cycle of human immunodeficiency virus-type 1 (HIV-1) showing a binding of the HIV-1 gpl20 to the specific CD4 receptor at the cell surface, followed by viral entry into the cytoplasm; $\mathbf{b}$ action of reverse transcriptase to transcribe proviral DNA from the HIV-1 RNA genome, followed by the integration of newly made proviral DNA into cellular DNA; c production of viral mRNA and proteins; and $\mathbf{d}$ viral assembly at the plasma membrane with the subsequent budding of progeny $H I V-1$ particles 
(11). This may help to explain the consistently encouraging results that have been obtained with this drug, since infected cells should otherwise be able to produce viral RNA, protein and progeny virus in an unrestricted fashion.

It is also true that AZT exerts an incomplete effect at best with regard to inhibition of viral reverse transcriptase activity. Many studies have shown that some proviral DNA synthesis and production of infectious progeny virus can occur, even when AZT is used to treat cells continuously over long periods, from times preceding viral inoculation to as long as three months $(12,13)$. For this reason, a number of laboratories have been anxious to develop other drugs which will be useful in the fight against HIV-1-associated disease. In certain cases, these drugs may also be nucleoside analogues like AZT, which may act by inhibiting viral reverse transcriptase activity. In other instances, there has been an effort to concentrate on inhibition of other steps in the HIV-1 replication cycle, such as the use of soluble CD4 to antagonize the specific binding of HIV- 1 to its specific receptor at the cell surface (14). Of course, the existence of AZT-resistant strains of HIV-1 raises the possibility that certain of these viruses might display cross resistance to other nucleosides that could otherwise be considered prospective therapeutic agents. The fact that cross resistance has been reported in select cases reinforces the need for the development of effective therapeutic agents that will successfully antagonize steps in the viral replication cycle other than reverse transcription of viral RNA to DNA.

\section{ISOLATION OF DRUG-RESISTANT STRAINS OF HIV- 1}

The initial report of isolation of HIV-1 with reduced sensitivity to AZT was based on a study carried out in a group of patients with advanced disease (AIDS or AIDS-related complex [ARC]), who had received drug therapy for more than three months. A heterogeneity of responsiveness to AZT was observed among a group of 18 isolates obtained from HIV seropositive, untreated individuals, with a $50 \%$ inhibitory dose (ID50) between 0.01 and $0.05 \mu \mathrm{M}$ (5). In contrast, a 100-fold increase in ID50 was commonly seen in isolates from patients who had received AZT for six months or more.

This study was followed by a report from the present authors' group which isolated HIV-1 from each of 72 asymptomatic, HIV-1 seropositive individuals entered into a Canadian multicentre AZT dose-finding study (6). Viruses with decreased sensitivity to AZT were isolated from the peripheral blood mononuclear cells of five of 20
TABLE 1

Isolation of strains of HIV-1 with reduced sensitivity to AZT

\begin{tabular}{lccc}
\hline $\begin{array}{l}\text { Number of } \\
\text { subjects }\end{array}$ & $\begin{array}{c}\text { Weeks of } \\
\text { treatment }\end{array}$ & \multicolumn{2}{c}{ Days to culture positivity* (mean) } \\
No AZT & AZT $(2 \mu \mathrm{M})$ \\
\hline 22 & $27-146$ & $6-16(10.6)$ & - \\
26 & $36-158$ & $5-19(10.2)$ & $10-24(15.4)$ \\
\hline
\end{tabular}

"Cultures were considered positive when they contained p24 antigen levels greater than $7 \mathrm{ng} / \mathrm{mL}$ and reverse transcriptase activity greater than $25,000 \mathrm{cpm} / \mathrm{mL}$. AZT Zidovudine

individuals who received AZT for longer than 36 weeks. The presence of these viruses was demonstrated both by the inclusion of a variety of concentrations of AZT (0.5 to $20 \mu \mathrm{M})$ directly into the primary tissue culture medium used for viral isolation, and by demonstration that frozen isolates of HIV-1, initially cultured in the absence of the drug, could subsequently be replicated in tissue culture in the presence of $1 \mu \mathrm{M}$ AZT.

The use of frozen isolates in this regard has enabled the comparison of drug-resistant variants of HIV-1 with wildtype parental strains derived from the same patients prior to drug therapy. In no instance has it been possible to demonstrate the development of drug resistance among strains of HIV-1 isolated from patients who had not received AZT therapy. The results in Table 1 show drug-resistant strains of HIV-1 on the basis of production of viral reverse transcriptase activity under conditions in which AZT was included in the viral culture medium. The authors have now succeeded in showing HIV strains with apparently reduced sensitivity to AZT in the case of 26 subjects of a total of 48 studied for this purpose. These data, along with those reported above (5),

\section{TABLE 2}

Stability of the AZT-resistant phenotype

\begin{tabular}{cccc}
\hline Isolate & $\begin{array}{c}\text { Duration of } \\
\text { viral replica- } \\
\text { fion in } \\
\text { absence of } \\
\text { AZT (days) }\end{array}$ & $\begin{array}{c}\text { RT activity }(\mathrm{cpm} / \mathrm{mL}) \\
\text { When } \\
\text { progeny } \\
\text { grown with }\end{array}$ & $\begin{array}{c}\text { When grown } \\
\text { AZT }(2 \mu \mathrm{M})\end{array}$ \\
\hline without AZT \\
\hline Resistant & 0 & 329,864 & 293,566 \\
variant A & 20 & 291,410 & 312,432 \\
& 30 & 426,575 & 286,775 \\
Resistant & 60 & 314,987 & 304,683 \\
variant B & 0 & 211,468 & 285,712 \\
& 20 & 283,522 & 238,901 \\
Resistant & 30 & 255,643 & 312,422 \\
variant C & 60 & 231,973 & 198,762 \\
& 0 & 218,789 & 215,618 \\
& 20 & 252,031 & 243,767 \\
Sensitive & 30 & 310,596 & 291,087 \\
control & 00 & 288,373 & 246,752 \\
& 0 & 1688 & 347,510 \\
& 30 & 1397 & 196,078 \\
& 60 & 2106 & 275,516 \\
\hline
\end{tabular}

AZT Zidovudine: cpm Counts per minute; RT Reverse transcriptase 
TABLE 3

Inhibitory effect of AZDU on infection of MT-4 cells by AZT-resistant variants of HIV-1

\begin{tabular}{|c|c|c|c|c|}
\hline $\begin{array}{l}\text { Strain of } \\
\text { HIV-1 }\end{array}$ & Compound & $\begin{array}{l}\text { Concen- } \\
\text { tration } \\
(\mu \mathrm{M})\end{array}$ & RT activity & $\begin{array}{l}\text { Fluores- } \\
\text { cent cells } \\
(\%)\end{array}$ \\
\hline $\begin{array}{l}\text { Resistant } \\
\text { variant A }\end{array}$ & AZDU & $\begin{array}{c}- \\
0.1 \\
0.5 \\
2 \\
0.1 \\
0.5 \\
2\end{array}$ & $\begin{array}{r}836,725 \\
164,255 \\
27,396 \\
3793 \\
457,912 \\
396,058 \\
347,511\end{array}$ & $\begin{array}{r}74 \\
9 \\
0 \\
0 \\
69 \\
76 \\
82\end{array}$ \\
\hline $\begin{array}{l}\text { Resistant } \\
\text { variant B }\end{array}$ & $\begin{array}{c}- \\
\text { AZDU } \\
\text { AZT }\end{array}$ & $\begin{array}{c}- \\
0.1 \\
0.5 \\
2 \\
0.1 \\
0.5 \\
2\end{array}$ & $\begin{array}{r}750,968 \\
43,516 \\
12,058 \\
2492 \\
543,019 \\
358,740 \\
412,631\end{array}$ & $\begin{array}{r}59 \\
6 \\
0 \\
0 \\
64 \\
72 \\
58\end{array}$ \\
\hline $\begin{array}{l}\text { Resistant } \\
\text { variant C }\end{array}$ & $\begin{array}{c}- \\
\text { AZDU } \\
\text { AZT }\end{array}$ & $\begin{array}{c}- \\
0.1 \\
0.5 \\
2 \\
0.1 \\
0.5 \\
2\end{array}$ & $\begin{array}{l}305,976 \\
248,734 \\
162,582 \\
120,633 \\
477,535 \\
356,792 \\
318,407\end{array}$ & $\begin{array}{l}64 \\
57 \\
41 \\
46 \\
65 \\
72 \\
60\end{array}$ \\
\hline $\begin{array}{l}\text { Resistant } \\
\text { variant D }\end{array}$ & AZDU & $\begin{array}{c}- \\
0.1 \\
0.5 \\
2 \\
0.1 \\
0.5 \\
2\end{array}$ & $\begin{array}{l}273,420 \\
308,964 \\
143,521 \\
137,655 \\
294,318 \\
242,547 \\
202,851\end{array}$ & $\begin{array}{l}58 \\
51 \\
42 \\
29 \\
56 \\
65 \\
60\end{array}$ \\
\hline $\begin{array}{l}\text { AZT-sensi- } \\
\text { tive clini- } \\
\text { cal strain }\end{array}$ & $\stackrel{-}{A Z Z U}$ & $\begin{array}{c}- \\
0.1 \\
0.5 \\
2 \\
0.1 \\
0.5 \\
2\end{array}$ & $\begin{array}{r}360.642 \\
74.596 \\
6.971 \\
1.589 \\
46.978 \\
5752 \\
1313 \\
\end{array}$ & $\begin{array}{r}71 \\
16 \\
0 \\
0 \\
12 \\
0 \\
0\end{array}$ \\
\hline
\end{tabular}

AZDU 3'-azido-23'-dideoxyuridine; AZT Zidovudine: HIV-1 Human immunodeficiency virus type 1: RT Reverse transcriptase

also make it clear that resistance to AZT is a relative rather than an absolute phenomenon. In each instance studied, time to culture positivity, demonstrated by the presence of either viral reverse transcriptase activity or p24 antigen in culture fluids, was greater when AZT was included in culture medium. Thus, all HIV-1 isolates studied, including those with an apparently drugresistant phenotype, are inhibited to some extent in the presence of AZT.

The results in Table 2 make clear that the development of the drug-resistant phenotype is a stable phenomenon. Viruses which possessed an AZT-resistant phenotype were cultured in the absence of drug for up to 60 days; when AZT was added back into the culture medium, viral replication was able to continue with efficiency. In addition, individuals from whom drug-resistant viruses were isolated, and who were subsequently maintained on antiviral therapy, continued to yield viruses which possessed a drug-resistant phenotype on subsequent occasions (5).

More recently, strains of HIV-1 showing decreased susceptibility to AZT have been reported by other groups (7). Comparisons of HIV-1 isolates, obtained both before and after treatment with AZT, have shown that the viral strains obtained after therapy were less susceptible to AZT, as assessed by replication under a variety of tissue culture conditions.

\section{CROSS RESISTANCE AND SENSITIVITY OF AZT-RESISTANT VARIANTS OF HIV-1 TO OTHER NUCLEOSIDES}

The initial report of HIV-1 resistance to AZT indicated that the isolates in question were also insensitive to another compound, widely considered for usefulness against HIV-1-associated disease (5). This drug is $3^{\prime}$-azido- $2^{\prime}, 3^{\prime}$-dideoxyuridine (AZDU). However, these isolates retained sensitivity to a variety of other compounds, including 2',3'-dideoxycytidine, 2',3'-dideoxy-2', $3^{\prime}$ didehydrothymidine and phosphonoformic acid. A subsequent study indicated that cross resistance only occurred in the case of nucleoside analogues containing a 3'-azido group (15). However, other investigators have indicated that cross resistance may also exist with regard to other nucleoside analogues, including dideoxyinosine and didehydrothymidine (6). In addition, the present authors' studies have suggested that not all strains of HIV-1 that are resistant to AZT are necessarily cross resistant to AZDU, although the AZDU-mediated inhibition observed occurred in a concentration-dependent manner (Table 3). Indeed, the present authors' data suggest that while some strains of HIV-1 that display resistance to AZT are indeed cross resistant to AZDU, other strains may be sensitive to the same extent as wildtype isolates of HIV-1. The authors have also employed a variety of other drugs with regard to assessment of drug sensitivity and resistance. These include dideoxycytidine, dideoxyinosine and phosphonoformic acid, as well as a novel drug termed deoxythiacytidine (IAF Biochem, Montreal), in which the $3^{\prime}$ carbon of the nucleoside pentose ring has been replaced by a sulphur atom. The data in Table 4 indicate that the latter compound was able to inhibit the replication of all variants of AZT-resistant HIV-1, and that the inhibition effected by this and other nucleosides against HIV-1 replication was equivalent to that displayed by AZT against wildtype HIV-1 isolates.

Thus, it appears that a heterogeneity of AZTresistant viral isolates may exist. In some instan- 
TABLE 4

Inhibitory effect of nucleoside analogues on infection of MT-4 cells by AZT-resistant variants of HIV-1

\begin{tabular}{|c|c|c|c|c|c|c|}
\hline \multirow[b]{2}{*}{ Viral phenotype } & \multirow[b]{2}{*}{ No drug } & \multicolumn{5}{|c|}{ RT activity* (cpm/mL) when viruses were replicated in presence of: } \\
\hline & & AZT $(1 \mu \mathrm{M})$ & $\mathrm{ddC}(1 \mu \mathrm{M})$ & ddl $(1 \mu \mathrm{M})$ & $\mathrm{BCH}-189(1 \mu \mathrm{M})$ & $\mathrm{d} 4 \mathrm{~T}(1 \mu \mathrm{M})$ \\
\hline AZT-sensitive & 286,512 & 2016 & 1738 & 1652 & 1055 & 1359 \\
\hline AZT-sensitive & 241,683 & 1739 & 1429 & 1293 & 1463 & 1805 \\
\hline AZT-resistant & 392,071 & 147,577 & 1568 & 1680 & 1681 & 141,098 \\
\hline AZT-resistant & 314,685 & 219,038 & 1422 & 26,311 & 1423 & 273,516 \\
\hline AZT-resistant & 362,592 & 242,176 & 1037 & 1645 & 1689 & 2369 \\
\hline AZT-resistant & 273,417 & 203,734 & 1580 & 1892 & 1037 & 1233 \\
\hline AZT-resistant & 247,990 & 182,926 & 1993 & 1405 & 1228 & 1840 \\
\hline
\end{tabular}

"Cultures were assessed for reverse transcriptase (RT) activity four days after inoculation of the MT-4 line of CD4+ lymphocytes. Drug was present $1 \mathrm{~h}$ after viral inoculation. AZT Zidovudine; ddC 2, 3'-dideoxycytidine; ddl Dideoxyinosine; BCH-189 Deoxythiacytidine; d4T 2, 3'-dideoxy-2,3'-didehydrothymidine

ces, certain of these isolates may display cross resistance to other nucleosides, while in other cases, no cross resistance may be present.

Furthermore, it appears that certain isolates of HIV-1, which display resistance to AZT, may show unequal patterns of cross resistance to other drugs, and no one isolate may be resistant to all other compounds. Moreover, it would appear that cross resistance against any particular nucleoside, such as AZDU, is unlikely to occur all of the time. This observed heterogeneity in patterns of drug sensitivity and resistance may be due, in part at least, to the stage of HIV-1-associated disease at which these viruses were isolated. The authors' studies have been conducted exclusively with strains of HIV- 1 isolated from asymptomatic individuals, and show heterogeneity of cross resistance to AZDU. In contrast, HIV-1 isolates studied by other investigators, which show much greater levels of cross resistance to AZDU, have all been isolated from patients with advanced disease (5).

\section{GENETIC BASIS FOR AZT-RESISTANCE}

As mentioned, mutations within the viral pol gene, which encodes the reverse transcriptase enzyme, is a likely basis for diminished sensitivity to AZT and other nucleosides. In this regard, it is interesting that site-directed mutagenesis studies on HIV-1 indicated that mutations within the pol region could yield viruses with diminished reverse transcriptase activity. These alterations were shown to cause an apparent reduction in binding affinity on the part of reverse transcriptase for a variety of antiviral agents, including phosphonoformic acid and AZT-triphosphate. It was concluded that mutations resulting in altered viral transcriptase activity would probably be detrimental to viral growth (16).

Subsequent analysis revealed that viruses which had been mutagenized in this way retained infectious potential, albeit at a reduced level (17). This suggested that high levels of efficient viral reverse transcriptase activity might be required for efficient viral replication. Viruses which had been subjected to site-directed mutagenesis within the pol region, and which possessed decreased levels of viral reverse transcriptase activity, could be shown to be less sensitive to phosphonoformic acid than wildtype viral strains. However, certain of these viruses showed decreased sensitivity to AZT-triphosphate in enzyme assays, yet paradoxically were sensitive to AZT when grown in tissue culture.

Another interesting result is the dichotomy between data obtained on the basis of direct measurements of viral reverse transcriptase activity in the presence of AZT-triphosphate, and drug resistance. Several groups have shown that viruses which replicated in the presence of AZT possessed reverse transcriptase molecules that were apparently insensitive to the effects of AZT-triphosphate measured directly under enzymatic conditions. This suggests that the conditions under which reverse transcriptase is measured may not accurately reflect the microenvironment of the cytoplasm in which viral RNA is converted to DNA.

The present authors' laboratory has further demonstrated that the stoichiometry of AZT-resistant variants is apparently unaltered in comparison with wildtype in the case of drug-resistant viral strains. The results in Table 5 show that the amounts of p5l/66 reverse transcriptase protein per amount of p24 antigen remained constant in the case of both AZT-resistant strains of HIV-1 and the wildtype parental strains from which they were derived. The parental strains in question had been isolated from the same patients prior to the commencement of AZT therapy. This research was conducted on the basis of a quantitative enzymelinked immunosorbent assay (ELISA) in which monoclonal antibodies against p5l/66 were used to determine the levels of this protein. Amounts of viral p 24 were measured by an ELISA commercially 


\section{TABLE 5}

Relationship between levels of p24 antigen and p51/66 antigen for parental wildtype and AZT-resistant isolates of HIV-1

\begin{tabular}{ccc}
\hline & \multicolumn{2}{c}{ ng p51/66 per ng p24 } \\
Viral isolate & AZT-resistant strain & Parental strain \\
\hline A & 0.071 & 0.077 \\
B & 0.277 & 0.262 \\
C & 0.092 & 0.058 \\
\hline
\end{tabular}

AZT Zidovudine: HIV-1 Human immunodeficiency virus type 1

TABLE 6

Rates of incorporation of dTTP and dGTP by RT enzymes of drug-resistant and wildtype strains of HIV-1

\begin{tabular}{lcccc}
\hline & \multicolumn{2}{c}{ dGTP } & \multicolumn{2}{c}{ dTTP } \\
Viral strain & $\begin{array}{c}\text { AZT- } \\
\text { resistant }\end{array}$ & Parental & $\begin{array}{c}\text { AZT- } \\
\text { resistant }\end{array}$ & Parental \\
\hline A & 2.05 & 0.06 & 9.39 & 0.5 \\
B & 1.85 & 0.12 & 10.37 & 0.65 \\
C & 2.15 & 0.35 & 10.48 & 3.29 \\
\hline
\end{tabular}

All studies were performed using $2000 \mathrm{ng}$ of viral p24 per test. AZT Zidovudine; dGTP Deoxyguanosine triphosphate; dTP Deoxythymidine triphosphate: HIV-1 Human immunodeficiency virus type 1

available for this purpose. Thus, resistance to AZT is not apparently associated with increased or decreased levels of viral p51/66 protein per virion.

The present authors have also studied the ability of the reverse transcriptase enzymes of these AZT-resistant and wildtype viruses to catalyze the incorporation of $\mathrm{H}^{3}$-dTTP into DNA. The data in Table 6 indicate that the reverse transcriptase enzymes of AZT-resistant variants were apparently more efficient than their parental counterparts in this regard. Two of the AZT-resistant viruses tested possessed increased reverse transcriptase catalytic efficiency in comparison with parental strains.

In this context, it is interesting that multiple, sequential mutations within the segment of the pol gene (which encodes reverse transcriptase activity) have been shown to confer high level resistance on AZT. Comparative analyses of nucleotide sequences of the reverse transcriptase coding region from five pairs of sensitive and resistant derivative isolates suggested that three amino acid substitutions could account for most of the drug resistance observed (16-18). These alterations corresponded to the change of aspartic acid to asparagine at position 67 , lysine to arginine at position 70 , and threonine to phenylalanine at position 215. In addition, a fourth genomic change was observed in three isolates, that of lysine to glutamine at position 219. Isolates of HIV- 1 which displayed only partial resistance to AZT had combinations of these various changes. Furthermore, it was shown that an infectious molecular clone which had been constructed with all four of these mutations possessed the highest levels of AZT resistance after transfection of T lymphocytes (18).

\section{CLINICAL SIGNIFICANCE OF DRUG RESISTANCE IN HIV- 1-ASSOCIATED DISEASE}

Drug-resistant strains of HIV-1 have now been isolated from over 30 of the 72 patients initially entered into the Canadian multicentre AZT trial carried out in asymptomatic individuals having CD4 lymphocyte counts higher than 500 cells $/ \mathrm{mm}^{3}$. Thus far, the authors have been unable to establish any definitive correlation between the presence or absence of drug-resistant strains of HIV-1, and the likelihood of disease progression, although there seems to be a trend in that direction. Of course, it will be necessary to continue to follow this cohort of patients over a long period to determine whether the emergence of drug-resistant strains of HIV-1 is likely to correlate ultimately with an enhanced likelihood of advanced disease. In contrast, studies by other investigators have apparently concluded that drug-resistant strains are more likely to be isolated from patients who have experienced or are likely to suffer from AZT treatment failure. The basis for such differences in results may be due to differences between the populations studied. In the present case, the authors have studied asymptomatic individuals only. Such individuals may possess a higher frequency of drug-resistant viruses that are only partially resistant to AZT and in which the successive mutations within the pol gene likely to account for the highest levels of drug resistance have not yet occurred. In this context, it may be significant that viruses which possess such mutations have only been isolated from patients with advanced HIV-1-associated disease, including ARC and AIDS (17). These are individuals who, in many cases, are likely to have been infected for longer periods of time than asymptomatic individuals, and in whom the dynamics of viral replication may differ significantly from those in patients with lesser disease. This may also help to explain the basis for total cross resistance to AZDU in the case of drug-resistant strains of HIV-1 isolated from AIDS patients, as opposed to the partial cross resistance seen in viruses isolated from subjects with asymptomatic disease.

Clearly, it will be necessary to continue to follow this cohort of asymptomatic individuals, still under investigation, over a long period in order to determine whether the development of drug resis- 
tance will correlate with a potential deterioration in clinical status. In light of recent reports indicating that treatment with AZT may be of benefit to asymptomatic patients in terms of retarding disease progression (10), it is likely that the development of drug-resistant strains of $\mathrm{HIV}-1$ will become more commonplace in this population. Such changes in accepted standards of treatment may alter the dynamics of the relationship between AZT and HIV-1 over the next several years, giving rise to the possibility that drug-resistant strains of HIV-1 will be isolated from asymptomatic patients in much higher frequencies than has previously been the case.

Clinicians must be wary not only of the pos-

ACKNOWLEDGEMENTS: Aspects of original work reported in this paper were supported by Health and Welfare Canada and by the Medical Research Council of Canada. The authors thank Ms S Fraiberg for typing the manuscript.

\section{REFERENCES}

1. Chen Y-C, Grill S, Ruth J, et al. Anti-herpes simplex virus and anti-human cell growth activity of E-5-propenyl-2'-deoxyuridine and the concept of selective protection in antivirus chemotherapy. Antimicrob Agents Chemother 1980;18:957-61.

2. Derse D, Bastow KF, Cheng Y-C. Characterization of the DNA polymerases induced by a group of herpes simplex virus type 1 variants selected for growth in the presence of phosphonoformic acid. J Biol Chem 1982;257:10251-60.

3. Plotkin SA, Drew WL, Felsenstein D, et al. Sensitivity of clinical isolates of human cytomegalovirus to 9-(1,3-dihydroxy2-propoxymethylguanine. J Infect Dis 1985;152:833-4.

4. Richman DD, Yazaki P, Hostetler KY. The intracellular distribution and antiviral activity of amantadine. Virology 1981;112:81-90.

5. Larder BA, Darby G, Richman DD. HIV with reduced sensitivity to zidovudine (AZT) isolated during prolonged therapy. Science 1989;243:1731-4.

6. Rooke R, Tremblay M, Soudeyns H, et al. Isolation of drug-resistant variants of HIV-1 from patients on long-term zidovudine therapy. AIDS 1989;3:411-5.

7. Land S, Treloar G, McPhee D, et al. Decreased in vitro susceptibility to zidovudine of HIV isolates obtained from patients with AIDS. J Infect Dis 1990;161:326-9.

8. Fischl MA, Richman DD, Grieco MM, et al. The efficacy of azidothymidine (AZT) in the treatment of patients with AIDS and AIDS-related complex. A double-blind placebo-controlled trial. N Engl J Med 1987;317:185-91. sibility of the emergence of drug-resistant strains possessing phenotypes similar to those previously described, but also that such strains in the future may possess greater virulence than parental wildtype viruses. An additional consideration, of course, is that of transmission of drug-resistant strains of HIV-1 among sexual partners and the possibility that the natural course of HIV-1-associated disease, in the case of drug-resistant viral strains, may differ from that which has been elicited thus far. It is clear that the emergence of this field poses enormous challenges to the understanding of AIDS and related diseases, and to the ability to manage this epidemic effectively in years to come.

9. Gelmon K, Montaner JSG, Fanning M, et al. Nature, time-course and dose dependence of zidovudine-related side effects: Results from the Multicenter Canadian Azidothymidine Trial. AIDS 1989;3:555-61.

10. Volberding PA, Lagakos SW, Koch MA, et al. Zidovudine in asymptomatic human immunodeficiency virus infection. N Engl J Med 1990;322:941-9.

11. Rooke R, Tremblay M, Weinberg MA. AZT (zidovudine) may act postintegrationally to inhibit generation of HIV-1 progeny virus in chronically infected cells. Virology 1990;176:205-15.

12. Mitsuya H, Jarrett RF, Matsukura M, et al. Long-term inhibition of human T-lymphotropic virus type III/lymphadenopathy-associated virus (human immunodeficiency virus) DNA synthesis and RNA expression in $T$ cells protected by 2',3'-dideoxynucleosides in vitro. Proc Natl Acad Sci USA 1987;84:2033-7.

13. Tremblay M, Wainberg MA. Susceptibility to AZT of HIV-1 variants grown in Epstein-Barr virus-transformed B cell lines. J Infect Dis 1989; 160:31-6.

14. Wainberg MA, Kendall O, Gilmore N. Vaccine and antiviral strategies against infections caused by human immunodeficiency virus. Can Med Assoc J 1988; 138:797-807.

15. Larder BA, Chesebro B, Richman DD. Susceptibilities of zidovudine-susceptible and -resistant human immunodeficiency virus isolates to antiviral agents determined by using quantitative plaque reduction assay. Antimicrob Agents Chemother 1990;34:436-41.

16. Larder BA, Kemp SD, Purifoy DJM. Infectious potential of human immunodeficiency virus type 1 reverse transcriptase mutants with altered inhibitor sensitivity. Proc Natl Acad Sci USA 1989;86:4803-7.

17. Larder BA, Purifoy DJM, Powell KL, et al. Site-specific mutagenesis of AIDS virus reverse transcriptase. Nature 1987;327:716-7.

18. Larder BA, Kemp SD. Multiple mutations in HIV-1 reverse transcriptase confer high-level resistance to zidovudine (AZT). Science 1989;246:1155-8. 


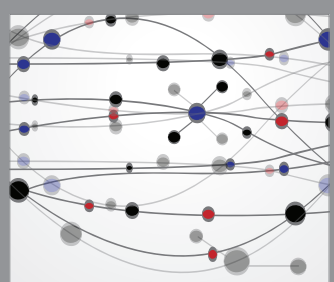

The Scientific World Journal
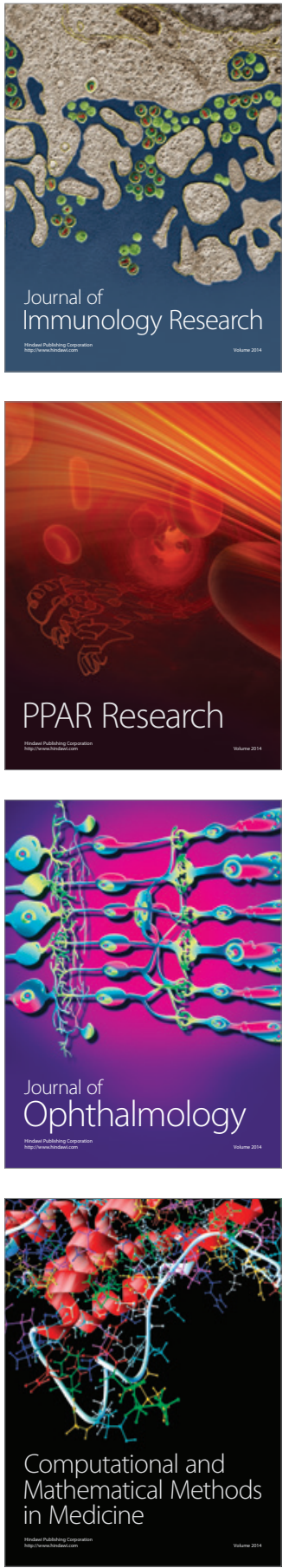

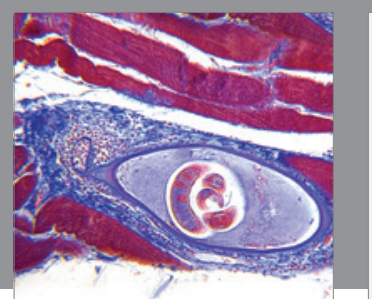

Gastroenterology Research and Practice

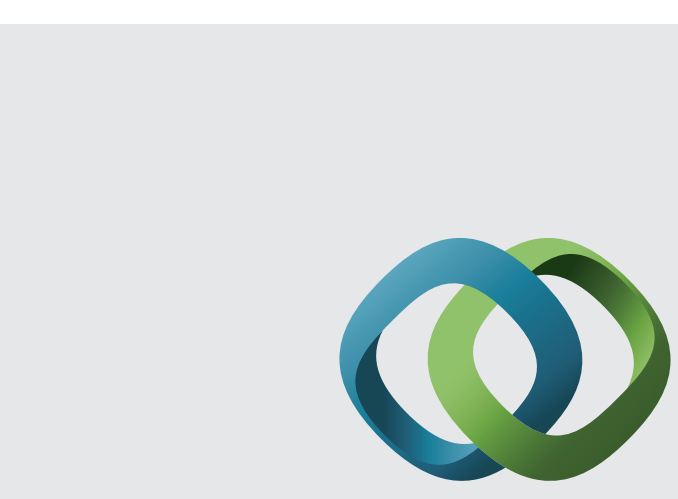

\section{Hindawi}

Submit your manuscripts at

http://www.hindawi.com
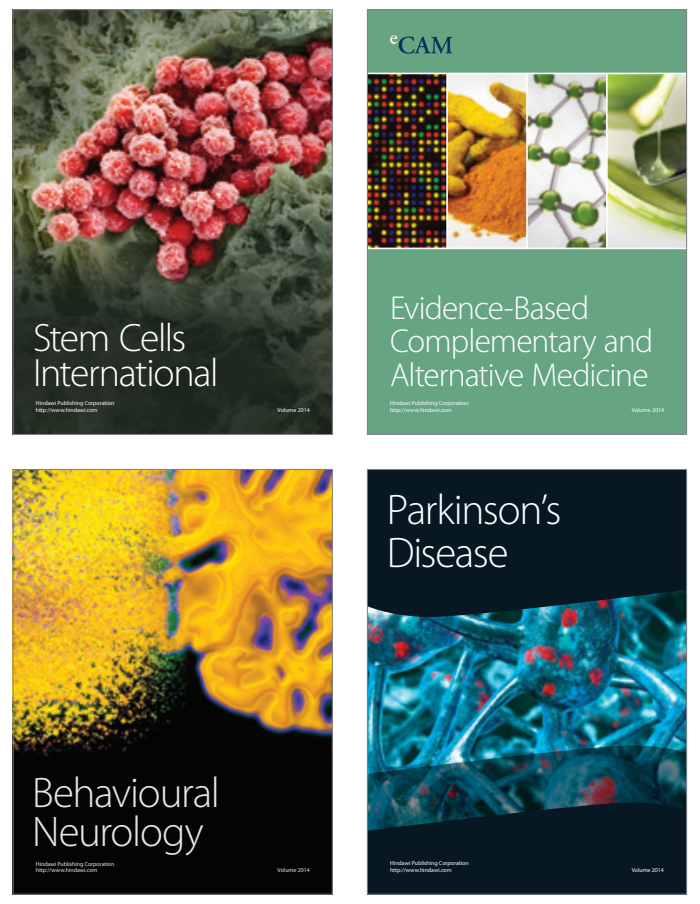
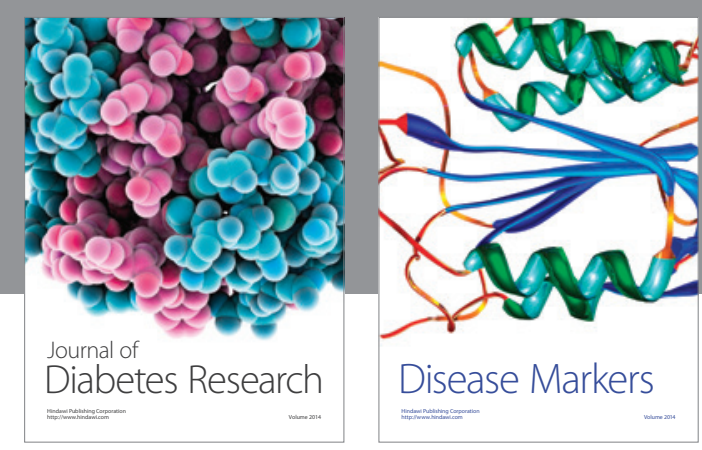

Disease Markers
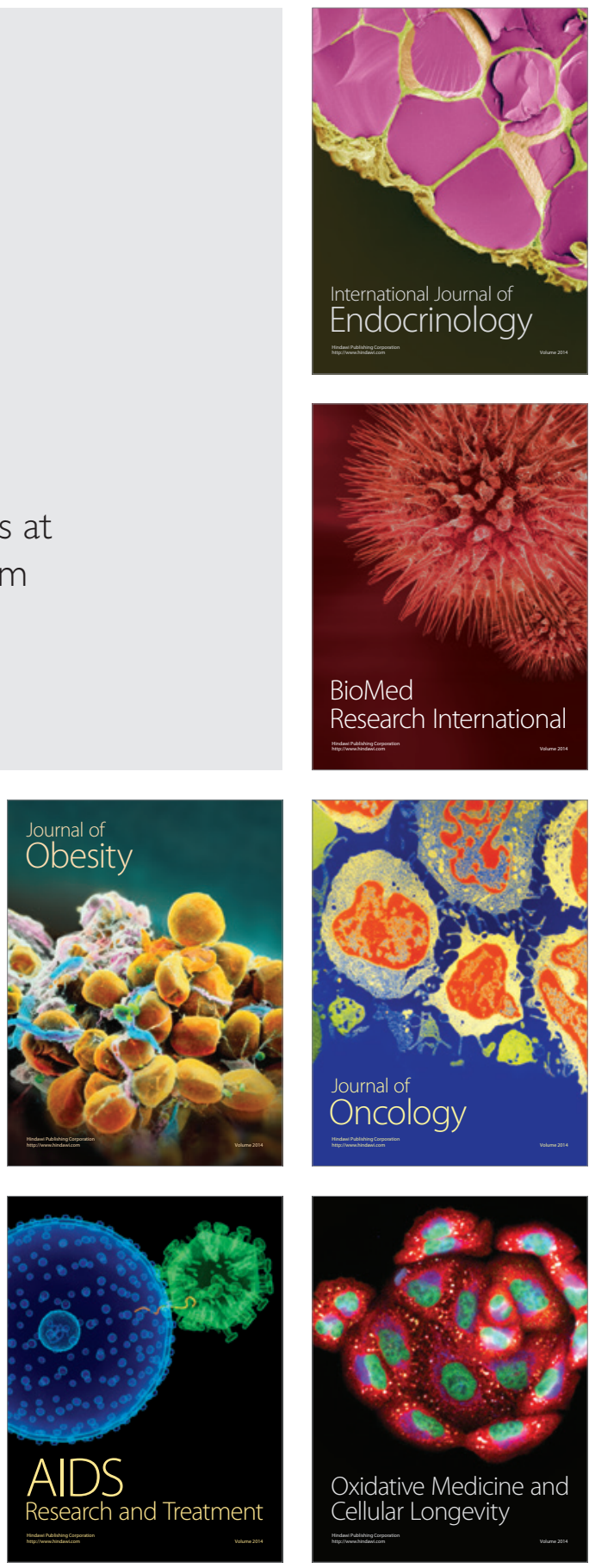